\title{
METODE TAFSIR PRODUK SAINS TERAPAN STUDI TENTANG TERAPI STEM CELL
}

\author{
Abdul Aziz \\ Institut PTIQ Jakarta \\ Email: abaziz.ta@gmail.com
}

\begin{abstract}
ABSTRAK
Kesimpulan dari penelitian ini adalah, menemukan rumusan baru tentang suatu metode tafsir produk sains terapan, yang relatif sederhana, mudah dimengerti, cepat, dan sistematis. Rumusan baru tersebut, juga diujicobakan pada satu produk sains terapan modern-kontemporer, yaitu terapi stem cell. Dan, hasilnya bahwa terapi stem cell untuk pengobatan penyakit degeneratif, perawatan tubuh (penuaan), maupun reproduksi, menurut syariat agama Islam dibolehkan secara bersyarat.

Rumusan metode tafsir produk sains terapan tersebut dibangun berlandaskan kepada hadis Nabi Muhammad SAW, yang isinya tentang tiga sumber dalil hukum Islam, Al-Qur'an, hadis dan ijtihad. Maka, dibangun metode tafsir produk sains terapan yang terdiri atas sepuluh langkah, dengan urutan sebagai berikut: objek (yang dalam penelitian ini adalah produk terapi stem cell), produk yang dikaji (bahan, proses, dan aplikasi), pemilihan metode tafsir yang akan digunakan, pemilihan bentuk tafsir, memastikan jenis tafsir ilmi, memastikan jenis tafsir ahkam, lakukan pencarian status hukumnya dalam Al-Qur'an, dan atau menelusuri hadis, dan atau menggunakan jenis ijtihad, sampai kepada keluaran sebagai hasil akhir dari kajian, yaitu produk sains terapan yang dimaksud dibolehkan atau tidak menurut syariat agama Islam?

Pendekatan yang digunakan di dalam merumuskan metode tafsir produk sains terapan dimaksud, penulis gunakan metode ijtihad ulama dalam beristinbâth hukum, yaitu menggunakan metode istinbâth hukum Majelis Ulama Indonesia (MUI) karena adanya kesamaan, yaitu metode pencarian hukum. Namun, rumusan metode tafsir produk sains terapan yang ditemukan pada penelitian ini, relatif lebih sederhana, lebih mudah dimengerti, lebih cepat dan lebih sistematis, dengan tingkat kebenaran yang dapat dipertanggungjawabkan, karena kajiannya menggunakan diagram alir sepuluh langkah untuk setiap tahapan kajian bahan, proses dan aplikasi dari semua produk yang dikaji.

Metode yang digunakan di dalam penelitian ini adalah metode kualitatif, dengan berlandaskan kepada tiga sumber dalil hukum Islam yang disusun secara sistematis dan penggunaannya tetap berpedoman kepada kaidah-kaidah ilmu fikih yang sudah ada.
\end{abstract}

Kata kunci: metode tafsir, tafsir sains terapan 


\begin{abstract}
The conclusion of this research is finding a new formulation of a method of interpretation of applied science products, which is relatively simple, easy to understand, fast, and systematic. The new formula was also tested on a moderncontemporary applied science product, namely stem cell therapy. And, the result is that stem cell therapy for the treatment of degenerative diseases, body care (aging), and reproduction, according to Islamic religious law is conditionally permissible.

The formulation of the method of interpretation of applied science products was built based on the hadith of the Prophet Muhammad, whose contents are about the three sources of Islamic law theorem, Al-Qur'an, Hadith and ijtihad. Then, the method of interpreting applied science products is constructed consisting of ten steps, in the following order: objects (which in this study are stem cell therapy products), the products studied (materials, processes, and applications), the selection of interpretation methods to be used, choosing the form of interpretation, ascertaining the type of scientific interpretation, ascertaining the type of legal interpretation, conducting a search for its legal status in the Qur'an, or tracing the hadith, and / or using the type of ijtihad, up to the output as the final result of the study, namely applied science products is it permissible or not according to Islamic law?

The approach used in formulating the interpretation method of applied science products is intended, the authors use the ijtihad ulama method in conducting legal search, that is, using the Indonesian Ulema Council's legal search method because of the similarity, namely the method of legal search. However, the formulation of the method of interpretation of applied science products found in this research is relatively simpler, easier to understand, faster and more systematic, with a level of truth that can be accounted for, because the study uses a ten-step flow chart for each stage of the study of materials, processes and application of all products being reviewed.

The method used in this study is a qualitative method, based on three sources of Islamic legal propositions that are arranged systematically and their use is still guided by the principles of fiqh that already exist.
\end{abstract}

Key words: interpretation method, interpretation of applied science

\title{
Pendahuluan
}

Dinamika penafsiran ayat-ayat sains (ayat-ayat kauniyah), baik ayat-ayat kecil (al-âyât al-shughrâ), atau firman Allah, ataupun disebut juga Kalamullah yang tertulis di dalam mushaf Al-Qur'an, maupun ayat-ayat besar (al-âyât alkubrâ), yaitu tanda-tanda kebesaran Allah yang bertebaran di alam semesta raya ini terus berkembang. ${ }^{1}$ Antara lain Nur Arfiyah Febriani, menjelaskan juga dalam karya bukunya, Ekologi Berwawasan Gender dalam Perspektif Al-Qur'an, bahwa Al-Qur'an adalah wahyu yang diturunkan dengan berbagai simbol tulisan dan kata yang terhimpun (the recorded Quran), sedangkan alam adalah wahyu dalam bentuk kosmik (takwin). Alam adalah sebuah buku yang berisi wahyu primordial. Dengan demikian dapat dipahami bahwa Al-Qur'an dan alam adalah 'kitab suci' Tuhan. ${ }^{2}$

${ }^{1}$ Mulyadhi Kartanegara, et.al., Pengantar Studi Islam, Jakarta: Ushul Press, 2011, hal. 129.

${ }^{2}$ Nur Arfiyah Febriani, Ekologi Berwawasan Gender, Dalam Perspektif Al-Qur'an, Cetakan I, Bandung: PT Mizan Pustaka, November 2014, hal. 246. 
Tanda-tanda kebesaran itu saat ini sedang dan terus bergeliat ${ }^{3}$ serta tumbuh secara progresif sejalan dengan tumbuh dan berkembangnya sains tersebut, juga sains terapan, seperti sains terapan dalam bidang bioteknologi (biasanya disingkat dengan biotek) serta bidang-bidang sains terapan lainnya.

Hal di atas terjadi dalam rangka upaya pemberdayaan sumber daya alam untuk kehidupan umat manusia yang lebih nyaman dan lebih baik. ${ }^{4}$ Pertumbuhan progresif juga terjadi pada banyak produk sains terapan modern-kontemporer yang aktual. ${ }^{5}$ Sayangnya, sampai dengan saat ini belum pernah ada satupun penelitian yang membahas tentang metode tafsir produk sains terapan, studi tentang terapi stem cell. Padahal, dalam beberapa dekade belakangan ini banyak produk sains terapan, utamanya produk sains terapan modern-kontemporer yang terus tumbuh dan berkembang secara berkesinambungan, tanpa batas. Seperti yang sudah penulis sebutkan di atas, yaitu terapi stem cell (teknologi pengobatan di bidang ilmu kedokteran), ${ }^{6}$ yang merupakan pengobatan atau penyembuhan penyakit pada organ tubuh manusia dengan teknologi terapi stem cell. Pertumbuhan produk sains terapan modern-kontemporer ini dapat dikatakan hampir tidak terkendali dan tanpa batas, utamanya pada dunia belahan Barat, di mana mereka ini secara terus menerus melakukan penelitian dan juga mendeklarasikan temuan-temuan barunya. ${ }^{7}$ Walaupun saat ini dunia belahan Timur juga sudah bisa mengimbanginya, namun relatif masih sedikit. Mulai dari tingkat kompleksitas yang paling sederhana, sampai dengan tingkat kompleksitas yang tinggi, dan juga kekinian. Sebagai contoh dalam bidang bioteknologi, yang merupakan perpaduan antara ilmu teknik, ilmu kimia dan ilmu biologi, seperti terapi stem cell, yang merupakan contoh objek yang akan dibahas dalam penelitian ini.

Di sisi lain Al-Qur'an, yang merupakan kitab suci umat Islam, mukjizat terbesar Nabi Muhammad SAW, juga dikatakan sholihun li kulli zaman wa makan, seharusnya mampu dengan cepat merespon atas semua produk sains terapan, yang dalam penelitian ini adalah tentang terapi stem cell, apakah dibolehkan atau tidak dibolehkan menurut syariat agama Islam? Karena sampai dengan saat ini belum ada satupun penelitian yang mengkaji tentang terapi stem cell.

Bahwa, terapi stem cell merupakan suatu produk sains terapan modernkontemporer, yang ayat-ayatnya tidak dapat secara eksplisit ditemukan di dalam Al-Qur'an (غَبْرُصَرِيْحِ). Padahal, dikatakan bahwa Al-Qur'an itu sholihun li kulli zaman wa makan, jadi ayatnya di dalam Al-Qur'an pastinya ada, namun secara implisit (غَيْرَصَرِيْحِ). Sehingga melalui metode tafsir yang dibangun pada penelitian ini, maka produk sains terapan, ataupun produk sains terapan modern-kontemporer yang dimaksud dapat diketahui, bahwa dibolehkan atau tidak dibolehkan menurut syariat agama Islam?

\footnotetext{
${ }^{3}$ Hery Harjono, et.al., Mengenal Ayat-Ayat Sains Dalam Al-Qur'an: Penciptaan Manusia, Dalam Perspektif Al-Qur'an dan Sains, Jilid 1, Cetakan I, Jakarta: Widya Cahaya, Rabi'ul Awal 1436 H/Januari 2015 M, hal. vii-viii.

${ }^{4}$ Humaidi, Paradigma Sains Integratif Alfarabi, Pendasaran Filosofis bagi Relasi Sains, Filsafat dan Agama, Cetakan Pertama, Jakarta Selatan 12430: Sadra Press, Jumadilakhir 1436 H/April 2015, hal. 76-77.

${ }^{5}$ Mahjuddin, Masail Al-Fiqh, Kasus-Kasus Aktual dalam Hukum Islam, Cetakan Ketiga, Jakarta: Kalam Mulia, 2012.

${ }^{6}$ National Academy of Sciences, Understanding Stem Cells, An Overview of The Science and Issues From The National Academies, National Academy of Engineering, t.tp: Institute of Medicine, National Research t.th.

${ }^{7}$ Charles Piddock, Teknologi Masa Depan, Dari Robot Manusia hingga Rumah Pintar, Konsultan: James Lee, t.tp: National Geographic, t.th.
} 
Di sisi lain sebetulnya sudah ada tafsir ayat ahkam yang dapat digunakan untuk mengkaji tentang sains, sehingga dapat diketahui bahwa sains tersebut dibolehkan atau tidak dibolehkan menurut syariat agama Islam? Namun tafsir ahkam di sini berangkat dari ayat yang ada di mushaf Al-Qur'an (ألَّنَّ) ke fenomena (آلَوَاقِعُع). Sedang metode tafsir yang dibangun pada penelitian ini adalah suatu metode tafsir produk sains terapan, yang menafsirkan suatu produk atau fenomena (آلَََاقِعُع) ke ayat-ayat yang ada di mushaf Al-Qur'an (آنََّصن), sehingga produk sains terapan atau produk sains terapan modern-kontemporer yang dimaksud yang harus direspon, dibolehkan atau tidak dibolehkan menurut syariat agama Islam? Produk sains terapan ini terus ditemukan dalam berbagai jenis, juga harus cepat direspon dan disikapi. Dari uraian di atas, maka terlihat bahwa pentingnya ilmuwan muslim untuk mempelajari ilmu Al-Qur'an. Sehingga kajiannya tidak sebatas pada persoalan etika (kode etik) saja.

Terbatasnya minat ilmuwan muslim yang kompeten di bidang sains terapan yang dimaksud untuk menekuni bidang ilmu tafsir Al-Qur'an, dan masih adanya sebagian dari ulama yang belum sependapat dengan keberadaan tafsir sains ini, ditengarai sebagai penyebab dari lambatnya umat Islam dalam merespon suatu produk sains terapan, utamanya produk sains terapan modern-kontemporer. Prokontra terhadap tafsir sains, termasuk tafsir sains terapan ini sudah lama ada, dan menjadi perdebatan para ulama sejak dari zaman ulama klasik, sampai dengan zaman ulama abad modern sekarang ini. Sedangkan menurut pendapat penulis, bahwa perkembangan sains belakangan ini, utamanya sains terapan modernkontemporer yang tumbuh dan berkembang begitu cepat tanpa batas, harus segera direspon dengan cepat pula oleh umat Islam.

Al-Qur'an yang dianggap shalihun li kulli zaman wa makan, sudah seharusnya dapat memberikan petunjuk dan juga dapat segera merespon, apakah produk sains terapan yang dimaksud dibolehkan atau tidak dibolehkan menurut syariat agama Islam? Selama ini relatif banyak produk kitab maupun buku, namun hanya membahas ayat-ayat ibadah, baik ibadah murni (mahdhoh) atau ibadah sosial (muamalah). Kalaupun ada tafsir tentang sains dari Al-Qur'an (al-âyât al-shughrâ), yang dibahas hanya sebatas tekstual dan kontekstual saja.

Sedangkan yang akan dibahas pada penelitian ini dengan judul, metode tafsir produk sains terapan, studi tentang terapi stem cell, seperti yang sudah disinggung di bagian atas, yaitu membangun suatu konsep metode tafsir, yang

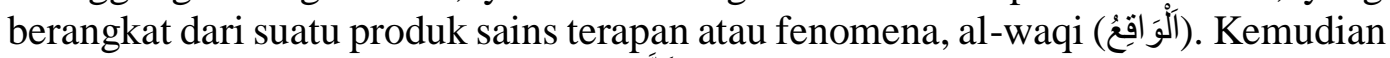
dicarikan dalil syariatnya, al-nash (آلنَّصن). Metode yang digunakan pada penelitian ini, adalah satu metode kualitatif, yaitu dengan cara mengkaji dan menganalisa suatu produk sains terapan secara sistematis, sehingga pada keluarannya (outcome) ditemukan suatu jawaban tentang produk sains terapan menurut syariat agama Islam, dibolehkan atau tidak dibolehkan.

\section{Pembahasan}

Ilmu pengetahuan (sains) dapat dibagi atas dua bagian pokok, ${ }^{8}$ yaitu alam materi dan alam nonmateri. Sedang yang akan dibahas pada penelitian ini hanya fokus kepada alam materi saja, dan disebut dengan ilmu kasbi, yaitu satu ilmu yang diperoleh karena upaya manusia, ${ }^{9}$ baik sebagai al-âyât al-shughrâ maupun al-âyât

${ }^{8}$ M. Quraish Shihab, Wawasan Al-Qur'an, Tafsir Tematik atas Pelbagai Persoalan Umat, Cetakan I, Bandung: Mizan Pustaka, Rabi’ Al-Tsani 1435 H/Februari 2014, hal. 574.

${ }^{9}$ M. Quraish Shihab, Wawasan Al-Qur'an, Tafsir Tematik atas Pelbagai Persoalan Umat, Cetakan I, Bandung: Mizan Pustaka, Rabi’ Al-Tsani 1435 H/Februari 2014, hal. 573. 
al-kubrâ, sedangkan ilmu ladunni tidak dibahas dalam penelitian ini. Selanjutnya Humaidi, dalam karya bukunya dengan judul, Paradigma Sains Integratif Alfarabi, Pendasaran Filosofis bagi Relasi Sains, Filsafat dan Agama, mengatakan bahwa sains modern dibagi atas empat kategori, yaitu: ${ }^{10} 1$. Sains alam semesta (natural science), 2. Sains murni (pure science), 3.Sains sosial kemasyarakatan (sociological science), 4. Sains terapan (applied science).

Pembahasan tentang sains alam semesta (natural science), sains murni (pure science) relatif sudah cukup banyak, baik dalam bentuk kitab tafsir maupun dalam bentuk buku-buku penelitian, begitu juga tentang sains sosial kemasyarakatan (sociological science) yang juga banyak dikaji oleh dunia belahan Barat, di mana mereka melihat Islam itu sebagai budaya. Sedangkan sains terapan (applied science), utamanya sains terapan modern-kontemporer, adalah suatu sains yang menempatkan teori-teorinya ke dalam praktek dengan tujuan mencari solusi dari suatu permasalahan pada umat manusia untuk meningkatkan kesejahteraannya. ${ }^{11}$

Beberapa dekade belakangan, bahwa sains terapan terus tumbuh dan berkembang dengan cepat secara berkesinambungan, dan tanpa batas. Utamanya sains terapan modern-kontemporer yang saat ini pertumbuhannya begitu cepat dan juga sangat beragam. Namun kajian syara'nya sampai dengan saat ini masih sangat sedikit. Kalaupun ada, itupun masih bersifat insidentil dan sporadis serta tidak sistemik. Jika ada permasalahan atau pertanyaan dari umat saja, dan kesemuanya itu mempunyai metode atau cara mengkajinya masing-masing. Dengan kata lain, belum ada yang menggunakan suatu cara atau suatu metode yang baku, dalam mencari jawaban dibolehkan atau tidak dibolehkan menurut syariat agama Islam, khususnya untuk produk-produk sains terapan, utamanya pada produk sains terapan modern-kontemporer. Kalaupun itu ada, seperti Lembaga Fatwa MUI, itupun belum ada unit yang khusus menangani produk-produk sains terapan ini utamanya produk-produk sains terapan modern-kontemporer. Padahal metode atau cara langkah standar yang dimaksud sudah seharusnya ada dan dibutuhkan untuk merespon dengan cepat bagaimana produk sains terapan, ataupun sains terapan modern-kontemporer dimaksud menurut syariat agama Islam, apakah dibolehkan atau tidak dibolehkan? Sejalan dengan hal tersebut, dan juga yang dibutuhkan para mufasir modern-kontemporer saat ini, adalah model metodologi baru dalam pembacaan serta pemahaman atas ayat-ayat Allah, agar 'kitab suci' Tuhan' ini benar-benar menjadi kitab petunjuk yang akan senantiasa relevan untuk setiap zaman dan tempat serta mampu merespon setiap problema sosial keagamaan yang dihadapi oleh umat Islam, atau dengan kata lainnya sholihun li kulli zaman wa makan.

Dari uraian di atas, maka jelaslah bahwa sampai dengan saat ini belum ada satupun penelitian tentang 'metode tafsir produk sains terapan, studi tentang terapi stem cell.' Artinya, bahwa penelitian ini merupakan sesuatu yang baru, dan layak untuk diangkat menjadi judul dalam penelitian ini. ${ }^{13}$

\footnotetext{
${ }^{10}$ Humaidi, Paradigma Sains Integratif Alfarabi, Pendasaran Filosofis bagi Relasi Sains, Filsafat dan Agama, Cetakan Pertama, Jakarta Selatan 12430: Sadra International Institute, 2015, hal. 76-77.

${ }^{11}$ Humaidi, Paradigma Sains Integratif Alfarabi, Pendasaran Filosofis bagi Relasi Sains, Filsafat dan Agama, Cetakan Pertama, Jakarta Selatan 12430: Sadra Press, Jumadilakhir 1436 H/April 2015, hal.76-77.

${ }^{12}$ Nur Arfiyah Febriani, Ekologi Berwawasan Gender, Dalam Perspektif Al-Qur'an, Cetakan I, Bandung: PT Mizan Pustaka, November 2014, hal. 246.

${ }^{13}$ Abdul Mustaqim, Epistemologi Tafsir Kontemporer, Cetakan III, Yogyakarta: LKIS Group, 2012, hal. v.
} 
Dilihat dari pengertian sains terapan, maka aplikasi ataupun implementasi produk sains terapan ini sepertinya sudah merambah ke semua bidang kehidupan, baik produk yang penciptaannya untuk kebutuhan umat manusia, seperti untuk meningkatkan kesejahteraan, kenyamanan hidup, kepentingan penelitian sampai dengan produk yang penciptaannya sekedar untuk hiburan ataupun kesenangan saja. Karena begitu banyaknya temuan baru dari produk sains terapan ini, sehingga sampai tertinggal atau tidak lagi sempat dikaji, dibolehkan atau tidak dibolehkan menurut syariat agama Islam? Sebagai contoh, temuan-temuan produk sains terapan modern-kontemporer terapi stem cell, yang merupakan salah satu temuan spektakuler di dalam dunia ilmu kedokteran, yang puncaknya adalah bahwa seorang perempuan dapat melahirkan seorang anak tanpa perlu ada intervensi ataupun melibatkan seorang laki-laki, dengan kata lain bahwa perempuan yang dimaksud 'sudah dapat memproduksi spermatozoa secara mandiri. ${ }^{14}$ Bahkan belakangan ini ada penelitian yang mengungkapkan adanya kehidupan di tubuh manusia yang telah meninggal dunia. ${ }^{15}$

Semua temuan-temuan di bidang ilmu kedokteran ini, seharusnya dapat segera direspon oleh para ilmuwan muslim, atau para peneliti muslim yang membidanginya, ataupun oleh ilmuwan muslim yang menekuni hukum agama Islam, bagaimana menurut hukum Islamnya? Banyak lagi contoh-contoh dari produk sains terapan lain, yang harus segera direspon dan disikapi oleh umat Islam, karena Islam tidak hanya mengajarkan dan memberikan petunjuk kepada umatnya dengan ibadah makhdhoh maupun ibadah sosial saja, namun agama Islam yang Rahmatan lil Alamin ini juga harus bisa menjawab kemajuan produk sains terapan, utamanya produk sains terapan modern-kontemporer. Sedang untuk mengetahui produk sains terapan modern-kontemporer dimaksud dibolehkan atau tidak dibolehkan menurut syariat agama Islam, maka sangat terkait dengan sumber dan dalil hukum agama Islam, yaitu: 1. Al-Qur'an, 2. Hadis, dan 3. Ijtihad, yaitu: ${ }^{16}$ Ijma', Qiyas, Istihsan, Istishlah (Maslahah Mursalah), Sadd Adz-Dzari'ah, Istishhab, 'Urf, Qaul Sahabiy

Seperti yang sudah disampaikan sebelumnya, bahwa dinamika perkembangan ilmu Al-Qur'an dan juga ilmu tafsir Al-Qur'an terus bergeliat ${ }^{17}$ dan berkembang dari waktu ke waktu menuju ke yang lebih baik, utamanya yang berkenaan dengan metode ilmu tafsirnya, sejalan dengan perkembangan ilmu pengetahuan belakangan ini. Pendapat para alim ulama, istilah tafsir dalam AlQur'an dapat dilihat pada surat al-Furqân [25]: 33.

Tidaklah orang-orang kafir itu datang kepadamu (membawa) sesuatu yang ganjil, melainkan Kami datangkan kepadamu suatu yang benar dan yang paling baik penjelasannya [1067].

[1067] Maksudnya: Setiap kali mereka datang kepada Nabi Muhammad SAW membawa suatu hal yang aneh berupa usul dan kecaman, Allah menolaknya

\footnotetext{
${ }^{14}$ Faried Anfasa Moeloek, Wawancara, tanggal 31 Oktober 2017, Jakarta: 31 Oktober 2017.

${ }^{15}$ https://today.line.me/id/pc/article/Riset+ini+Ungkap+Ada+Kehidupan+di+Tubuh+Man usia+yang+Telah+Mati-B1K6E0, Rabu,12-Juni-2019, Jam12.15 WIB

${ }^{16}$ Asmawi. Perbandingan Ushul Fiqh, Ed.1, Cetakan 2, Jakarta: Amzah, 2013, hal. 81167.

${ }^{17}$ Hery Harjono, et. al., Mengenal Ayat-Ayat Sains Dalam Al-Qur'an: Penciptaan Manusia, Dalam Perspektif Al-Qur'an dan Sains, Jilid 1, Cetakan I, Jakarta: Widya Cahaya, 2015 M, hal. viiviii.
} 
dengan suatu yang benar dan nyata.

Jadi, pada dasarnya pengertian tentang tafsir tidak terlepas dari kandungan makna menjelaskan, menerangkan, memerinci suatu kata yang masih dianggap samar. Tafsir juga dapat diartikan melahirkan, mengungkap serta menampakkan makna sesuatu yang masih belum terungkap dengan jelas. Perkembangan metode tafsir tidak terlepas dari kebutuhan umat manusia untuk dapat dengan cepat merespon atas persoalan keagamaan yang timbul sebagai akibat dari kemajuan zaman.

Nashruddin Baidan, dalam karya bukunya yang diberi judul Metodologi Penafsiran Al-Qur'an, mengatakan bahwa sampai dengan saat ini ada empat metode tafsir Al-Qur'an, yaitu sebagai berikut: ${ }^{18}$ a. Metode ijmali (metode global b.Metode tahlili (metode analitis) c. Metode muqarin (metode perbandingan), d.Metode maudhu'i (metode tematik)

Selanjutnya, di samping empat metode tafsir Al-Qur'an di atas, masih ada dua bentuk dan juga beberapa corak tafsir. Kesemuanya itu masuk ke dalam komponen internal, sedang komponen eksternalnya adalah jati diri Al-Qur'an itu sendiri dan juga kepribadian mufasirnya. Hal ini dapat dilihat pada gambar skema ilmu tafsir berikut: ${ }^{19}$

Perkembangan kemajuan akan sains terapan yang begitu cepat, utamanya sains terapan modern-kontemporer, harus diantisipasi dan juga disikapi serta diimbangi dengan kecepatan dalam pembacaan dan pemahaman terhadap makna teks Al-Qur'an dengan cepat dan akurat. Hal ini berarti bahwa paradigma lama tentang pemahaman Al-Qur'an harus digeser dan diubah, dari paradigma lama yang literalis-ideologis menjadi paradigma baru yang kritis-kontekstual, ${ }^{20}$ yang berarti bahwa, dibutuhkan suatu model atau metodologi baru dalam hal pembacaan dan pemahaman terhadap Al-Qur'an, yaitu metode analitis komparatif.

Sejarah perkembangan tentang tafsir teks mushaf Al-Qur'an, sejak zaman Nabi Muhammad SAW, sampai dengan zaman modern-kontemporer saat ini, berdasarkan perspektif the history of idea Ignaz Goldziher, telah terjadi pergeseran paradigma, dan dapat dipetakan menjadi tiga periode dengan basis penalarannya sebagai berikut: ${ }^{21}$ a). Periode Formatif, yaitu periode penafsiran Al-Qur'an yang terjadi di zaman Nabi Muhammad SAW dan para Sahabat hingga zaman pasca Sahabat. Di mana nalar yang digunakan pada periode ini, adalah nalar quasi-kritis. b). Periode Afirmatif, yaitu periode penafsiran Al-Qur'an yang terjadi di abad pertengahan Islam. Di mana nalar yang digunakan pada periode ini adalah nalar ideologis. c). Periode Reformatif, yaitu periode penafsiran Al-Qur'an yang terjadi di zaman modern-kontemporer. Di mana nalar yang digunakan pada periode ini adalah nalar kritis.

Bahwa, Fazlur Rahman dan juga Muhammad Syahrur termasuk mufasir modern-kontemporer. Langkah yang ditempuh oleh mereka ini dapat dikatakan relatif progresif dan prospektif. Metode pembacaan dan penafsiran yang ditawarkan oleh mereka diharapkan melahirkan sesuatu pembacaan yang kreatif dan produktif,

\footnotetext{
${ }^{18}$ Nashruddin Baidan, Metodologi Penafsiran Al-Qur'an, Cetakan I, Yogyakarta: Pustaka Pelajar, 1998, hal. 3.

${ }^{19}$ Nashruddin Baidan, Metodologi Penafsiran Al-Qur'an, Cetakan I, Yogyakarta: Pustaka Pelajar, 1998, hal. 9.

${ }^{20}$ Abdul Mustaqim, Epistemologi Tafsir Kontemporer, Cetakan III, Yogyakarta: LKIS Group, 2012, hal. v.

${ }^{21}$ Abdul Mustaqim, Epistemologi Tafsir Kontemporer, Cetakan III, Yogyakarta: LKIS Group, 2012, hal. vi-vii.
} 
sehingga ajaran-ajaran normatif-universal dari mushaf Al-Qur'an dapat dikontekstualisasikan sesuai dengan zamannya.

\section{Gambar Skema Ilmu Tafsir (Menurut Nashruddin Baidan)}

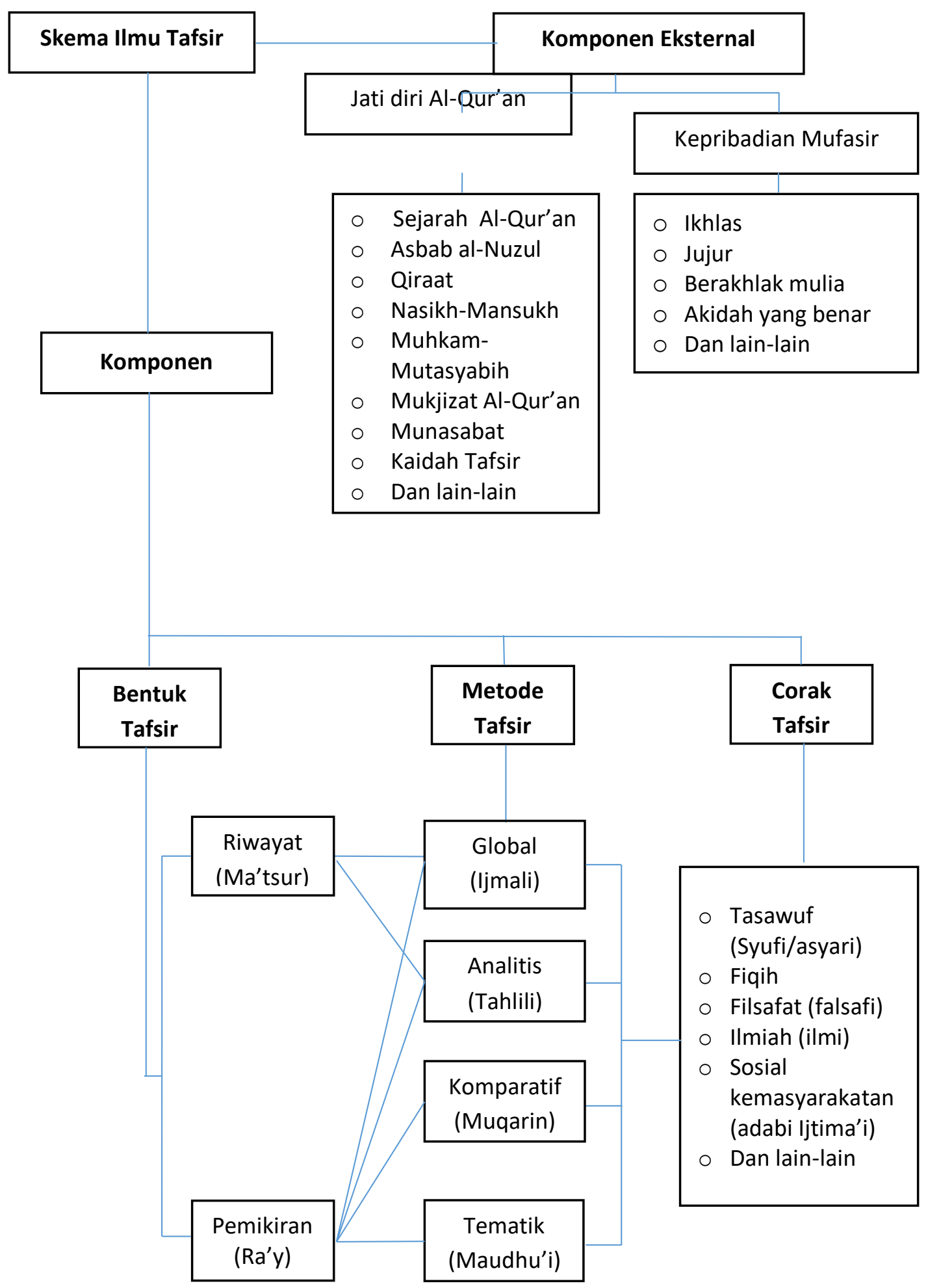


Dewasa ini, umat Islam sedang dihadapkan pada sejumlah persoalan yang menyangkut banyak aspek kehidupan, di mana salah satunya adalah sebagai akibat dari perkembangan produk sains, yang dalam penelitian ini adalah produk sains terapan, utamanya produk sains terapan modern-kontemporer, Di mana umat Islam dituntut untuk keluar dari kemelut tersebut dengan cara melakukan ijtihad. ${ }^{22}$ Menurut Yusuf Qardhawi, bahwa seseorang diperbolehkan melakukan ijtihad, minimal harus memiliki delapan syarat pokok, sebagai berikut: ${ }^{23} 1$.Memahami ayat-ayat Al-Qur'an dan asbabun nuzul-nya,2. Memahami hadis dan asbabul wurud-nya., 3. Menguasai bahasa Arab.

1. Mengetahui tempat-tempat ijma.'5.Memahami ushul fiqih.,6. Memahami maksud-maksud syariat.7.Memahami masyarakat dan adat-istiadatnya.8.Bersifat adil dan takwa. Selain syarat-syarat di atas, para ulama menambahkan tiga syarat lain: 1. Menguasai ilmu ushuluddin atau tauhid atau aqidah.2.Memahami ilmu mantik (logika), dan 3. Menguasai cabang fikih.

Sandaran ijtihad di atas harus berdasarkan pada dalil-dalil dari Al-Qur'an, hadis atau sunnah, dan juga ijma para sahabat. Dalam sebuah hadis disebutkan tentang pentingnya berijtihad, sebagaimana hadis Amru bin Al-Ash (diriwayatkan oleh Imam Al-Bukhari, Muslim, dan Ahmad), bahwa Nabi Muhammad SAW bersabda: $^{24}$

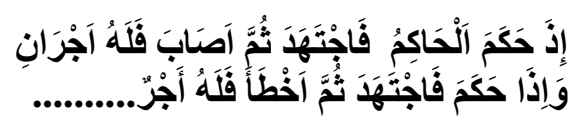

Apabila seorang hakim memutuskan masalah dengan jalan ijtihad kemudian benar, maka ia akan mendapat dua pahala dan apabila dia memutuskan dengan jalan ijtihad kemudian keliru, maka ia hanya mendapatkan satu pahala.

Begitu juga diriwayatkan, tatkala Mu'adz bin Jabal diutus ke Yaman, ditanya oleh Rasulullah SAW sebagai berikut:

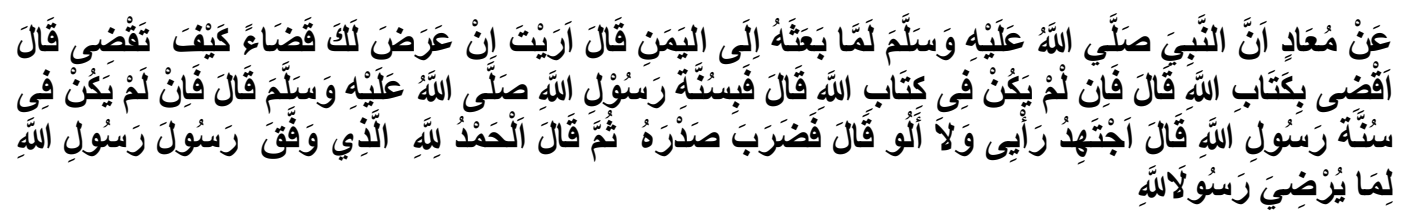

Bagaimana kamu akan memutuskan suatu hukum, jika dihadapkan pada suatu perkara?Mu'adz menjawab: Aku akan memutuskannya dengan 'Kitabullah.' Rasul pun bertanya kembali: Jika kamu tidak mendapatinya kembali di dalam Kitabullah? Mu'adz menjawab: (Aku akan memutuskannya) dengan 'sunnah Rasulullah SAW.'Rasul pun bertanya kembali: Jika kamu tidak mendapatinya di dalam sunnah Rasulullah?Mu'adz menjawab dengan mantap:Aku akan 'berijtihad' dan tidak akan teledor (sembarangan) dalam ijtihad tersebut. Rasul pun menepuk dada

\footnotetext{
${ }^{22}$ Syaikh Abdul Wahhab Khallaf, Al-Ijtihad fi Asy-Syariah Al-Islamiyyah, diterjemahkan oleh, Rohidin Wahid dengan judul, Ijtihad dalam Syariat Islam, Cetakan I, Jakarta: Pustaka AlKautsar, Maret 2015, hal. vii.

${ }^{23}$ Syamsul Rijal Hamid, Buku Pintar Hadits, Edisi Revisi, Jakarta: Qibla, 2013, hal. 577578

${ }^{24}$ Syaikh Abdul Wahhab Khallaf, Al-Ijtihad fi Asy-Syariah Al-Islamiyyah, diterjemahkan oleh, Rohidin Wahid dengan judul, Ijtihad dalam Syariat Islam, Cetakan Pertama, Jakarta: Pustaka Al-Kautsar, 2015, hal. vii-viii.
} 
Mu'adz sambil bersabda:Segala puji bagi Allah SWT yang telah memberi petunjuk kepada utusan Rasulullah SAW terhadap hal yang diridhoi Rasulullah SAW. [HR. Abu Dawud di dalam Al-Aqdhiyah (11), At-Tirmidzi di dalam Al-Ahkam (3), AnNasa'i di dalam Al-Qadha (81), dan Ahmad di dalam musnadnya (1, 27, dan 220)]. ${ }^{25}$

Dari uraian dan penjelasan di atas, maka jelaslah bahwa ijtihad dibolehkan dalam Islam, baik ijtihad mutlak maupun ijtihad terikat (muqayyad). Dewasa ini umat Islam sedang dihadapkan pada banyak persoalan kehidupan. Walaupun demikian, tetap hanya kepada mereka yang memiliki kemampuan ilmu pengetahuan (sains dan ilmu agama) yang dibolehkan untuk berijtihad dengan syarat-syarat tertentu. Dengan cara demikian maka umat Islam dapat terhindar dari perbuatan $b i d$ ' $a h^{26}$ yang sangat dilarang di dalam ajaran agama Islam, tetapi umat Islam tetap dapat merespon dan mensikapi perkembangan sains dengan cepat, tepat dan benar.

Di samping dua macam ijtihad di atas, ada lagi dua jenis ijtihad yang dikenal, yaitu ijtihad insyâî dan ijtihad intiqâî. ${ }^{27}$ Yaitu, jika dalam melaksanakan suatu ijtihad ditemukan hal-hal yang baru, sementara sumber rujukannya terbatas, misalkan masalah kontemporer, biasanya masalah sains, sains terapan, atau sains terapan modern-kontemporer, maka para ulama dalam menetapkannya secara kolektif (ijtihad jamâ' $\hat{\imath}$ ) dengan tetap terikat kepada kaidah-kaidah hukum atau istinbâth yang berlaku, dan dengan mendengarkan dahulu keterangan para ahlinya. Langkah semacam ini disebut dengan istilah ijtihad insyâî. Namun jika masalah yang akan ditetapkan tersebut sudah ada, di dalam mazhabnya, sehingga para pengambil keputusannya sudah bisa memutuskan, maka keputusan itu adalah yang terbaik (intiqâî). Dari penjelasan di atas dan proses yang harus ditempuh oleh seorang mujtahid, maka dapat disimpulkan bahwa dalam berijtihad dan menggali hukum-hukum syara,' maka dibutuhkan seseorang ataupun sekelompok orang yang telah memenuhi persyaratan sebagai mujtahid.

Seiring makin maju dan kompleknya permasalahan keagamaan dan kemasyarakatan, khususnya pertumbuhan di bidang sains terapan, utamanya sains terapan modern-kontemporer, maka semakin terasa kebutuhan pemahaman yang mendalam tentang hukum syariat agama Islam. Tentunya juga tentang ijtihad, baik ijtihad individual, maupun ijtihad kolektif yang biasa dikenal dengan ijtihad jama'i. Di Indonesia, ada empat institusi yang mengelola ijtihad jama'i, dan sudah cukup dikenal oleh masyarakat, yaitu: Majelis Tarjih dan Pengembangan Pemikiran Islam, dikelola oleh organisasi Muhammadiyah. ${ }^{28}$ b) Dewan Hisbah PERSIS, dikelola oleh organisasi Persatuan Islam (PERSIS). ${ }^{29}$ c) Lembaga Syuriyah atau

${ }^{25}$ Syaikh Abdul Wahhab Khallaf, Al-Ijtihad fi Asy-Syariah Al-Islamiyyah, diterjemahkan oleh, Rohidin Wahid dengan judul, Ijtihad dalam Syariat Islam, Cetakan Pertama, Jakarta: Pustaka Al-Kautsar, Maret 2015, hal. 9.

${ }^{26}$ Abdul Ilah bin Husain Al-'Arfaj, Mafhum Al-Bid'ah wa Atsaruhu fil Fatwa, diterjemahkan oleh, Mohamad Taufik Q. Hulaimi, et.al., dengan judul, Konsep Bid'ah dan Toleransi Fiqih, Cetakan Kedua, Jakarta: Al-I'tishom, Agustus 2013, hal. 36-37.

${ }^{27}$ M. Asrorun Ni'am Sholeh, Metodologi Penetapan Fatwa Majelis Ulama Indonesia, Penggunaan Prinsip Pencegahan dalam Fatwa, Jakarta: Emir-Erlangga, 2016, hal. 133-135.

${ }^{28} \mathrm{https}$ ://tarjih.or.id/sejarah-majelis-tarjih/ Jakarta 13 Juli 2019, Jam 23.10 WIB.

${ }^{29}$ Rafid Abbas, Ijtihad Persatuan Islam, Cetakan I, Yogyakarta: Pustaka Pelajar, 2013. 
Bahtsul Masâ'il, dikelola oleh organisasi Nahdlatul Ulama (NU) ${ }^{30}$ d) Komisi Fatwa Majelis Ulama Indonesia, dikelola oleh Majelis Ulama Indonesia (MUI). ${ }^{31}$

Dari ke-empat institusi istinbâth hukum yang mengelola ijtihad jama'i di atas. Penulis memilih untuk menelisik lebih jauh metode yang digunakan oleh Komisi Fatwa Majelis Ulama Indonesia (MUI), sebagai pendekatan langkah metode tafsir sains terapan yang penulis bangun. MUI, sudah mempunyai sistem dan prosedur untuk menetapkan suatu fatwa hukum yang dikenal metode istinbâth hukum. Metode penetapan fatwa ini berlaku dalam penetapan tiga kategori fatwa berikut: 1.Fatwa-fatwa ekonomi syariah, 2.Fatwa-fatwa produk halal, 3.Fatwafatwa keagamaan. Dari ke-tiga kategori metode penetapan fatwa di atas, secara eksplisit tidak dikatakan ada metode penetapan fatwa untuk produk sains terapan, namun dikatakan metode penetapan fatwa yang sifatnya insidentil dengan sebutan dan 'kecuali jika disebutkan secara spesifik.'

Bahwa, pembahasan metode tafsir sebelumnya ini relatif lebih ditekankan untuk tafsir mushaf teks Al-Qur'an, yang terdapat secara eksplisit dalam mushaf teks Al-Qur'an (صَرِيْحُ), yang oleh Mulyadhi Kartanegara, et.al., dalam karya bukunya dengan judul Pengantar Studi Islam, disebut dengan istilah al-âyât alshughrâ. ${ }^{32}$ Berbeda dengan produk terapi stem cell, yang merupakan suatu produk sains terapan modern-kontemporer. Ayat-ayatnya tidak dapat secara eksplisit diketemukan di dalam Al-Qur'an (غَيْرُصَرِيْنِ), walaupun dikatakan bahwa Al-Qur'an adalah sholihun li kulli zaman wa makan. Jadi ayat-ayatnya di dalam Al-Qur'an pasti ada, namun secara implisit (غَيْرُصَرِيْيُعْ). Sedang untuk dapat mengetahui apakah produk sains terapan modern-kontemporer yang dimaksud dibolehkan atau tidak dibolehkan menurut syariat agama Islam? Maka diperlukan suatu metode tafsir produk sains terapan, untuk menafsirkan produk sains terapan tersebut atau

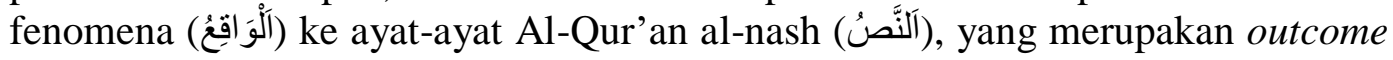
dari penelitian ini dengan judul, 'metode tafsir produk sains terapan, studi tentang terapi stem cell.' Penulis mengambil judul penelitian tersebut, karena terapi stem cell merupakan salah satu produk sains terapan modern-kontemporer, yang termasuk ke dalam kategori bidang bioteknologi, dn karena sains terapan di bidang bioteknologi ini ke depannya diperkirakan akan terus tumbuh dan berkembang secara berkesinambungan tanpa batas, sehingga akan banyak timbul pertanyaan berkaitan dengan hukum syara'nya.

Dalam penelitian ini penulis membangun konsep metode tafsir produk sains terapan, studi tentang terapi stem cell, yang merupakan kajian tentang metode istinbâth hukum atas suatu produk sains terapan, yang terus tumbuh cepat, berkesinambungan tanpa batas. Istinbâth hukum yang penulis jadikan sebagai pendekatan di sini adalah istinbâth hukum MUI, karena menurut pendapat penulis, bahwa MUI bisa mewakili institusi lain yang ada di Indonesia, atau dapat dikatakan mewakili Pemerintah Indonesia dalam persoalan ini. . Setelah penulis telisik lebih jauh, ternyata juga bahwa metode istinbâth hukum MUI tidak terlalu jauh dengan metode tafsir produk sains terapan yang penulis bangun, yaitu cara atau metode tafsir produk sains terapan yang sebelumnya belum pernah ada. Sedangkan untuk menyederhanakan prosesnya, penulis membagi produk sains terapan, ke dalam tiga tahapan bagian kajian, sebagai berikut: 1.Tahapan bagian kajian bahan (row

\footnotetext{
${ }^{30} \mathrm{https} / / / \mathrm{www} . g o o g l e . c o m /$ search?q=bahtsul+masa\%27il\&rlz=IC9BKJA_enID7 27ID728\&oq=...Jakarta, 13 Juli 2019, Jam 23.30 WIB.

${ }^{31}$ Ma'ruf Amin, et. al., Himpunan Fatwa Majelis Ulama Indonesia Sejak 1975, Jakarta: Erlangga, 2011.

${ }^{32}$ Mulyadhi Kartanegara, et.al., Pengantar Studi Islam, Jakarta: Ushul Press, 2011, hal. 129.
} 
material), 2.Tahapan bagian kajian proses (processing), 3.Tahapan bagian kajian aplikasi (applied). Metode pembagian atas tiga tahapan kajian ini tidak ditemukan pada metode istinbâth hukum MUI. Menurut pendapat penulis hal ini sangat diperlukan, karena akan sangat membantu, agar analisanya bisa lebih mudah, lebih sederhana, lebih cepat dan lebih sistematis, utamanya untuk produk sains terapan dengan kompleksitas yang tinggi.

Pembangunan konsep diagram alir metode tafsir produk sains terapan ini, penulis terinspirasi dari riwayat Mu'adz bin Jabal ketika diutus ke Yaman. Di mana, ijtihad dijadikan sebagai salah satu sumber dan dalil hukum Islam. Di sini Penulis ingin mencuplik ulang satu hadis yang diriwayatkan oleh Imam Bukhari, Muslim dan Ahmad, di mana Nabi Muhammad SAW bersabda: 33 "Apabila seorang hakim menetapkan hukum dengan berijtihad kemudian ia benar, maka ia mendapatkan dua pahala. Akan tetapi, jika ia menetapkan hukum dalam ijtihad kemudian ia salah, maka ia mendapatkan satu pahala."

Dari uraian di atas, maka diagram alir dimaksud dapat disusun seperti dapat dilihat pada halaman berikut:

${ }^{33}$ Syaikh Abdul Wahhab Khallaf, Al-Ijtihad fi Asy-Syariah Al-Islamiyyah, diterjemahkan oleh, Rohidin Wahid dengan judul, Ijtihad dalam Syariat Islam, Cetakan Pertama, Jakarta: Pustaka Al-Kautsar, Maret 2015, hal. vii-viii. 


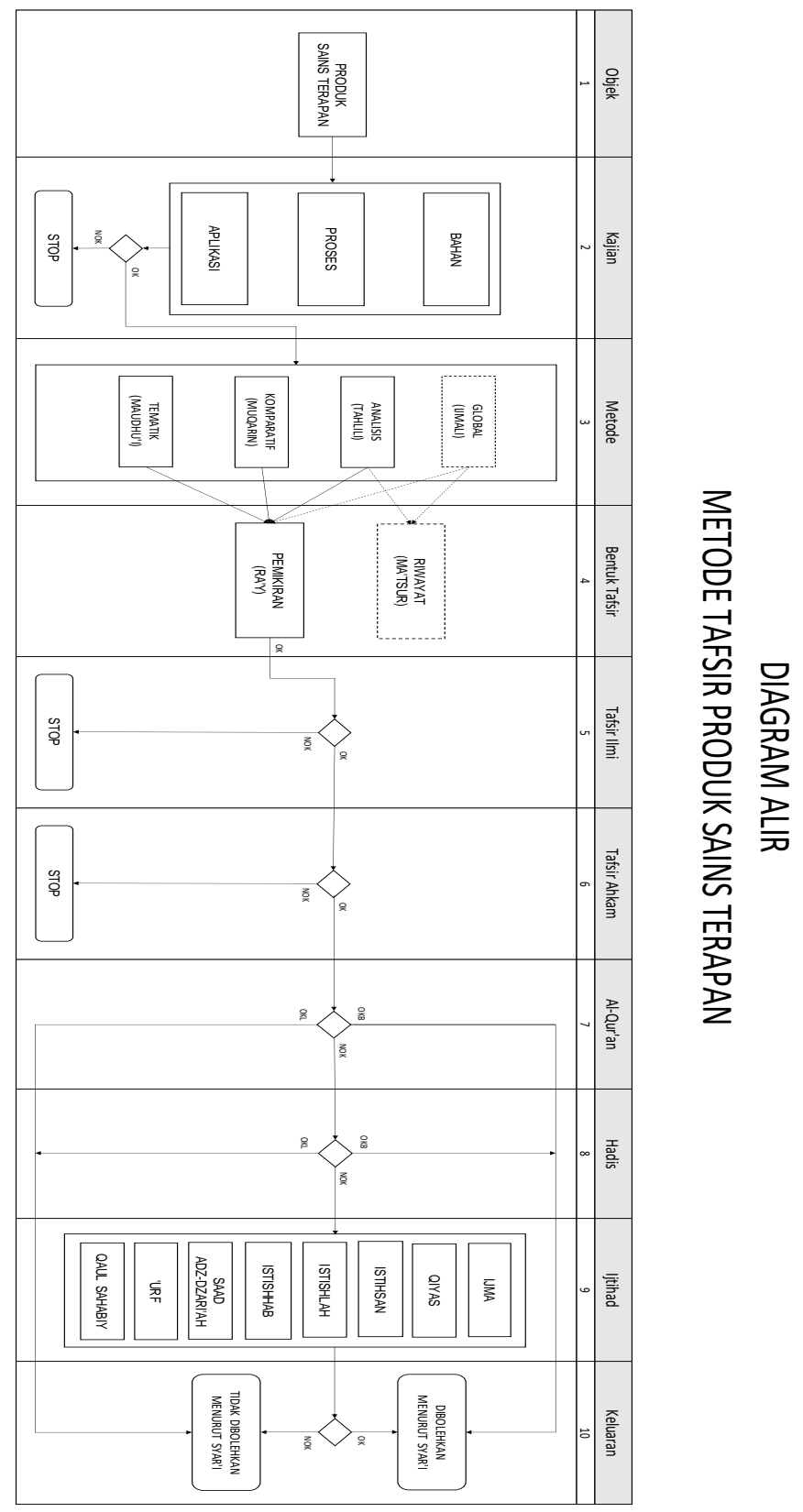

Diagram alir metode tafsir produk sains terapan di atas dapat dijadikan sebagai panduan untuk mengetahui tentang dibolehkan atau tidak dibolehkannya menurut ajaran syariat agama Islam, tentang suatu produk sains terapan, atau produk sains terapan modern-kontemporer. Bahwa, penjelasan dan penggunaan diagram alir dimaksud, yang terdiri atas sepuluh kolom, dapat dijelaskan sebagai berikut: a.Kolom objek, merupakan kolom masukan dari produk yang akan dijadikan objek dari produk yang akan dikaji, dalam hal ini adalah produk sains terapan. b.Kolom kajian, merupakan kolom di mana objek dari produk sains terapan yang akan dikaji dibagi atas tiga bagian kajian yang akan dianalisa masing-masing bagian kajiannya. c. Kolom metode, merupakan kolom di mana untuk menentukan metode yang dipilih dalam menafsirkan produk sains terapan, pada masing-masing bagian tahapan proses bahan, proses dan aplikasi. d.Kolom bentuk tafsir, merupakan kolom yang sama dengan kolom metode, yaitu kolom menentukan pemilihan bentuk tafsir..e.Kolom tafsir ilmi, merupakan kolom pengecekan corak tafsir. f. Kolom tafsir ahkam, merupakan kolom pengecekan corak tafsir. g.Kolom 
Al-Qur'an, merupakan kolom untuk pemeriksaan menurut tafsir Al-Qur'an (pencarian ayat-ayat yang terkait). h. Kolom hadis, merupakan kolom untuk pemeriksaan hadis. i.Kolom ijtihad, merupakan kolom pengkajian penggunaan ijtihad, apakah menggunakan ijma,' dan atau qiyas, dan atau istihsan, dan atau istishlah, dan atau istishhab, dan atau saad adz-dzari'ah, dan atau 'urf, dan atau qaul sahabiy, dalam rangka menentukan istinbâth hukum syara'nya. j. Kolom keluaran, merupakan kolom keluaran (outcome), yang merupakan hasil setelah pengkajian suatu produk sains terapan.

Jadi langkahnya dimulai dari masukan produk sains terapan di kolom pertama sampai dengan keluaran akhir (outcome) di kolom ke-sepuluh, yang merupakan keluaran atau hasil dari kajian suatu produk sains terapan yang dimaksud, di mana masing-masing tahapan bagian kajiannya adalah sebagai berikut: a.Bahan dasar objek (row material object), b. Proses pembuatan objek (prosessing object), c.Aplikasi objek (application object). Secara sederhananya, cara menerapkan atau memakai langkah metode tafsir produk sains terapan ini, adalah dengan cara seperti di atas, yaitu dari langkah ke-satu sampai dengan langkah ke-sepuluh dari diagram alir akan diperoleh bahwa bagian kajian bahan, apakah sesuai menurut syariat agama Islam? Demikian seterusnya untuk kajian proses dan kajian aplikasi.

Diagram alir langkah metode tafsir produk sains terapan di atas, adalah suatu konsep ilmiah, yang relatif sistematis, lebih sederhana, lebih mudah dimengerti, dan juga mudah diimplementasikan. 'Metode tafsir produk sains terapan' di atas, di samping dapat digunakan untuk kajian tafsir sains terapan, dapat juga dikembangkan untuk kajian tafsir produk sains sosial atau sains muamalah. Juga bisa dicoba untuk kajian tafsir sains murni, dan sains alam semesta. Untuk itu diagram alir langkah metode tafsir produk sains terapan dimaksud dapat dijadikan sebagai acuan ataupun referensi, dan akan lebih baik jika diagram alir ini distandardisasi, untuk mempercepat menjawab dibolehkan atau tidaknya suatu produk sains terapan ditinjau menurut syariat agama Islam.

\section{Implementasi Metode Tafsir Produk Sains Terapan}

Sebagai contoh Implementasi konsep metode tafsir produk sains terapan pada penelitian ini, adalah terapi stem cell. Dibolehkan, atau tidak dibolehkan menurut syariat Agama Islam?

\section{Kajian Teoritis Terapi Stem Cell}

Terapi stem cell, yang dalam bahasa Indonesia disebut sebagai terapi sel punca, ${ }^{34}$ adalah suatu terapi yang akhir-akhir ini ramai dibicarakan di dunia ilmu kedokteran Barat maupun Timur. Sejumlah keunikan yang dimiliki stem cell, membuatnya berbeda dengan sel-sel lain yang menyusun tubuh kita. Karakteristik dari setiap sel ini, telah memberikan harapan baru, bahwa tersedianya terapi medis bagi para penderita penyakit degeneratif, ${ }^{35}$ antara lain stroke, parkinson, cancer,

${ }^{34}$ Danny Halim, et.al., Stem Cell, Dasar Teori \& Aplikasi Klinis, Jakarta 13740: Erlangga, 2010, hal. 3. Stem Cell, merupakan tema sentral riset biomedis dewasa ini, yang akan mengubah konsep pengobatan dimasa depan.

${ }^{35} \mathrm{https} / / / \mathrm{www} . g o o g l e . c o m / s e a r c h ? \mathrm{q}=$ definisi+penyakit+degeratif\&rlz=IC9BKJA_enID72 7ID..., tanggal 21/6/2019, jam 5.45WIB, Penyakit Degeratif adalah kondisi kesehatan, di mana organ atau jaringan terkait keadaannya yang terus menurun seiring waktu. 
alzheimer, diabetes mellitus tipe1 dan lain-lain. ${ }^{36}$ Selain dari hasilnya yang menakjubkan, persentase tingkat keberhasilan juga cukup tinggi.

Sesuai dengan kata yang menyusunnya (yaitu, stem=batang, dan cell=sel), maka stem cell ini pula yang menjadi awal mula dari pertumbuhan sel lain, yang menyusun keseluruhan tubuh organisme, termasuk manusia. Layaknya sebuah batang pohon yang menjadi tumpuan bagi pertumbuhan ranting dan dahannya, stem cell juga merupakan awal dari pembentukan berbagai jenis sel penyusun tubuh.Oleh karena itu, dalam bahasa Indonesia belakangan ini istilah stem cell diterjemahkan sebagai sel punca, yang berarti sel awal mula. ${ }^{37}$

Makna yang terkandung dalam kata 'sel punca' ini, makin diteguhkan dengan penemuan keberadaan stem cell pada awal dari kehidupan manusia, yaitu saat masih embrio. Hal ini tentunya makin menegaskan bahwa stem cell merupakan sel yang menjadi awal mula terbentuknya sekitar 200 jenis sel yang menyusun tubuh. $^{38}$

Terkait dengan hakekatnya, maka belakangan ini stem cell telah menjadi topik utama pembicaraan banyak ilmuwan, ahli medis, bahkan orang awam di seluruh penjuru dunia, karena stem cell dipercaya dapat menjadi jalan keluar dari berbagai penyakit degeneratif. Bahwa, salah satu yang menyebabkan terjadinya penyakit degeneratif ini adalah kerusakan sel-sel dalam jaringan atau organ tubuh, sehingga jaringan atau organ tersebut tidak berfungsi sesuai dengan kebutuhan tubuh. ${ }^{39}$ Kersakan ini berifat ireversible ${ }^{40}$ sedangkan obat-obatan yang tersedia saat ini hanya bersifat untuk memperlambat atau mencegah terjadinya kerusakan jaringan atau organ yang lebih luas lagi. Dasar pemikiran inilah, maka para ahli berpikir bahwa stem cell adalah tumpuan terapi kedokteran di masa yang akan datang.

Beberapa keistimewaan yang dimiliki oleh stem cell, sehingga diperkirakan bahwa terapi stem cell ini dapat mengganti keberadaan sel tubuh yang rusak, mengingat stem cell adalah sel yang belum memiliki bentuk dan juga fungsi yang spesifik, seperti halnya sel neuron, sel $\beta$ pankreas atau sel otot jantung.

Fedik A. Rantam, menggambarkan stem cell sebagai berikut: ${ }^{41}$ 2010, hal. 4 .

${ }^{36}$ Danny Halim, et.al., Stem Cell, Dasar Teori \& Aplikasi Klinis, Jakarta 13740: Erlangga,

${ }^{37}$ Danny Halim, et.al., Stem Cell, Dasar Teori \& Aplikasi Klinis, Jakarta 13740: Erlangga, 2010, hal. 4 .

${ }^{38}$ Danny Halim, et.al., Stem Cell, Dasar Teori \& Aplikasi Klinis, Jakarta 13740: Erlangga, 2010, hal. 4. Tubuh kita tersusun oleh lebih dari 100 (seratus) triliun sel, yang terdiri dari sekitar 200 jenis sel yang berbeda fungsinya satu sama lain.

${ }^{39} \mathrm{https} / / / \mathrm{www}$.google.com/search?q=definisi+penyakit+degeratif\&rlz=IC9BKJA_enID72 7ID..., tanggal 21/6/2019, jam 5.45 WIB, Penyakit Degeneratif adalah kondisi kesehatan, di mana organ atau jaringan terkait keadaannya yang terus menurun seiring dengan waktu.

${ }^{40} \mathrm{https} / / / \mathrm{www} . g o o g l e . c o m / s e a r c h$ safe=strict\&rlz=1C9BKJA_enID727ID728\&ei=P7gN

XYyNIsP., tanggal 21-06-2019, jam 11.55 WIB. ireversible artinya terjadi penambahan substansi disertai perubahan bentuk atau struktur sel dan perubahan susunan kimia, sehingga terjadi pertumbuhan searah yang tidak dapat kembali ke bentuk asal.

${ }^{41}$ Fedik A. Rantam, Stem Cell Processing And Animal Trial, The $1^{\text {st }}$ Surabaya International in Stem Cell Biomedical Sciences, Unair Surabaya, November $\left(2-4^{\text {th }}\right), 2018$. 


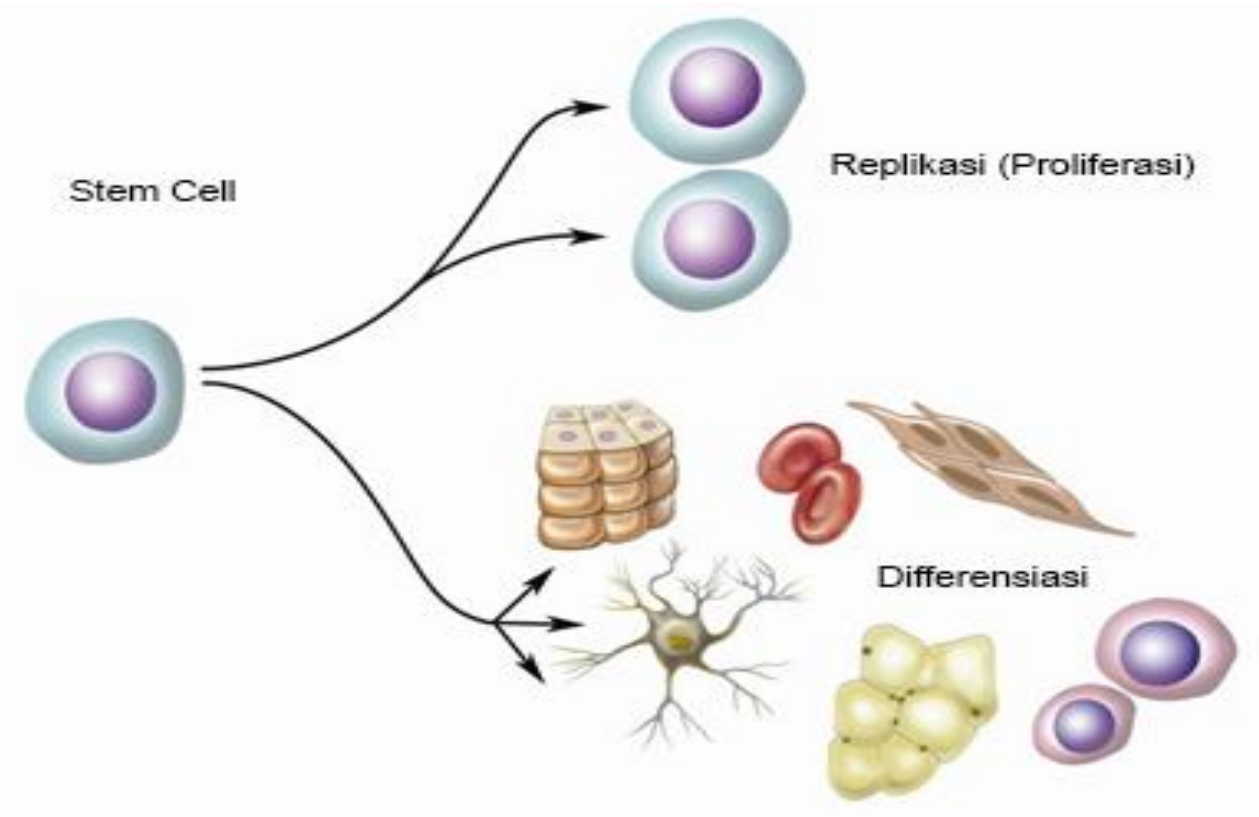

Gambar Stem Cell

Selanjutnya, menurut Danny Halim, et. al., di dalam karya bukunya Stem Cell, Dasar Teori \& Aplikasi Klinis, bahwa suatu sel dapat digolongkan sebagai stem cell, maka sel tersebut harus memiliki sejumlah karakteristik, antara lain sebagai berikut: ${ }^{42}$

a. Belum Berdiferensiasi (undifferentiated)

Belum memiliki bentuk dan fungsi spesifik, serta layaknya sel lain pada organ tubuh.

b. Mampu Memperbanyak Diri Sendiri (self renewal)

Dapat melakukan replikasi dan menghasilkan sel-sel replika dalam rangka memperbanyak dirinya dan menghasilkan sel-sel yang berkarakteristik sama dengan sel induknya.

c. Dapat Berdiferensiasi Menjadi Lebih Dari satu Jenis Sel

Belum memiliki bentuk dan fungsi yang spesifik (undifferentiated).

Berdasarkan sumber keberadaannya, stem cell dibagi atas: ${ }^{43}$

a. Stem cell embrionik (embryonic stem cell)

b. Stem cell dewasa (adult stem cell) berikut: ${ }^{44}$

Jenis stem cell atau sel punca yang dimaksud dapat dilihat pada gambar

${ }^{42}$ Danny Halim, et.al., Stem Cell, Dasar Teori \& Aplikasi Klinis, Jakarta 13740: Erlangga, 2010, hal. 5-7.

${ }^{43}$ Danny Halim, et.al., Stem Cell, Dasar Teori \& Aplikasi Klinis, Jakarta 13740: Erlangga, 2010, hal. 8 .

${ }^{44}$ Fedik A. Rantam, Stem Cell Processing And Animal Trial, The $1{ }^{\text {st }}$ Surabaya International in Stem Cell Biomedical Sciences, Unair Surabaya, November (2-4 $\left.{ }^{\text {th }}\right), 2018$. 


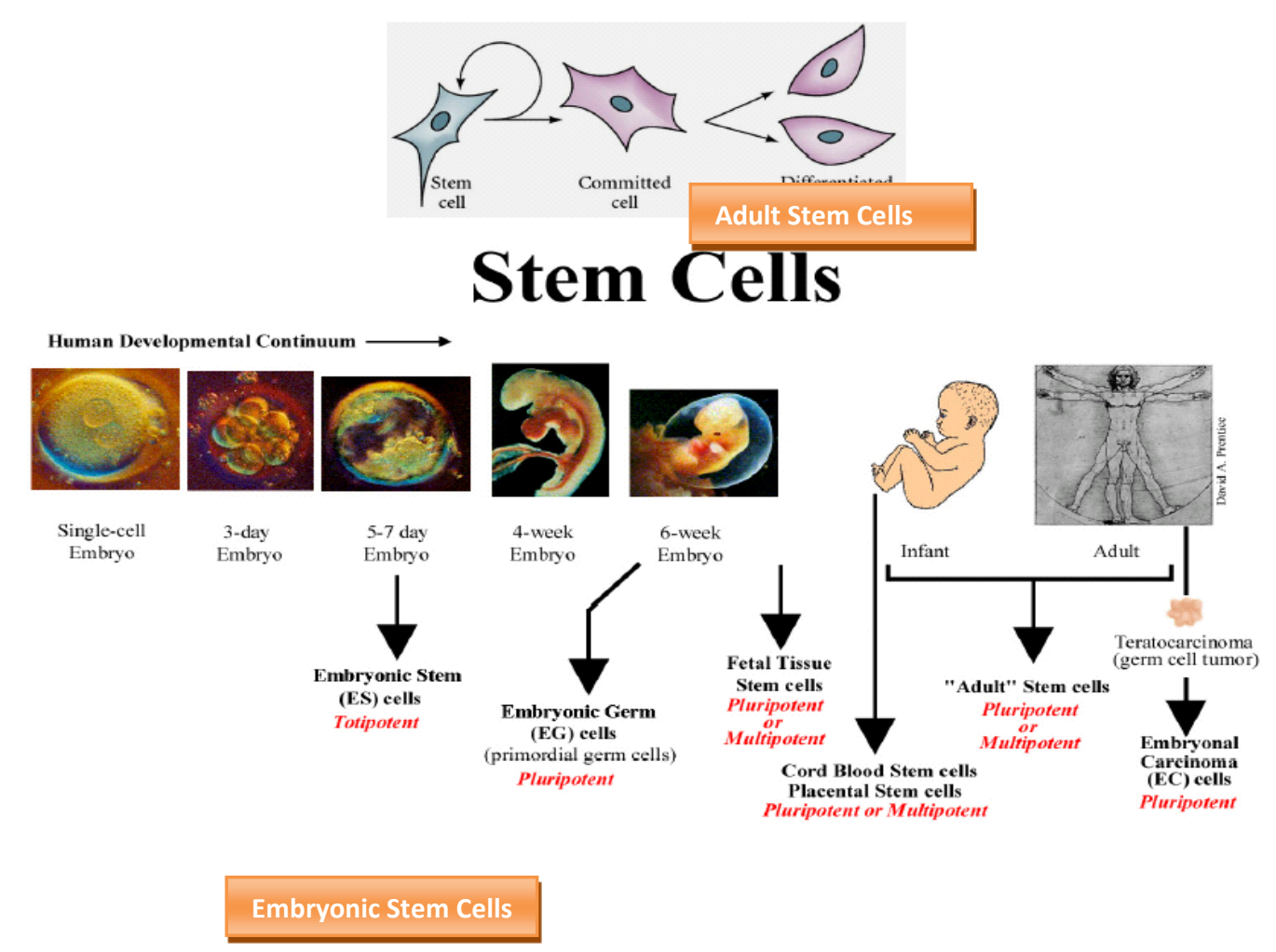

Gambar Jenis Stem Cell

a. Stem Cell Embrionik (embryonic stem cell)

Stem cell embrionik, ${ }^{45}$ adalah stem cell yang diperoleh pada saat perkembangan individu masih berada dalam tahap embrio. Lebih tepatnya, stem cell ini adalah massa sel dalam (inner cell mass) yang terdapat di dalam blastosis. Inner cell mass terbentuk saat embrio baru berusia 3 sampai dengan 5 hari. Saat di mana blastosis terbentuk, dan akan mengimplantasikan dirinya ke dalam dinding rahim.

Stem cell embrionik merupakan awal dari seluruh jenis sel di dalam tubuh manusia. Stem cell embrionik tergolong sebagai stem cell yang bersifat pluripoten. Inilah keistimewaan dari stem cell embrionik, yang sulit disaingi oleh stem cell jenis lainnya. Dengan dasar sifatnya yang pluripoten, secara logis tidak ada satupun penyakit degeneratif yang tidak dapat diobati. Sedang yang menjadi kekurangan dari penggunaan stem cell embrionik ini, baik dalam bidang riset maupun dalam bidang uji klinis pada tubuh manusia, terkait dengan nilai etika penggunaan embrio sebagai sumber didapatkannya sel ini. Karena hal ini pula, maka riset di seputar stem cell embrionik pada umumnya menggunakan embrio hewan, yang tentunya memberikan hasil yang tidak dapat disamakan dengan embrio manusia. Untuk melakukan suatu riset stem cell embrionik manusia, para peneliti telah berupaya dengan berbagai metode atau cara yang dianggap tidak bertentangan dengan nilai etika, tentunya termasuk kloning terapeutik,

${ }^{45}$ Danny Halim, et.al., Stem Cell, Dasar Teori \& Aplikasi Klinis, Jakarta 13740: Erlangga, 
Selain kloning terapeutik, partenogenesis juga merupakan salah satu metode atau cara yang banyak digunakan, dengan harapan tidak bertentangan dengan nilai-nilai etika yang berlaku.

b. Stem Cell Dewasa (adult stem cell)

Stem cell dewasa, ${ }^{46}$ adalah stem cell yang ditemukan di antara sel-sel lain yang telah berdiferensiasi dalam suatu jaringan yang telah mengalami maturasi. Stem cell dewasa adalah sekelompok sel-sel yang belum berdiferensiasi, bahkan terkadang ditemukan dalam keadaan 'inaktif' pada suatu jaringan yang telah memiliki fungsi spesifik pada tubuh individu. Keberadaan stem cell ini diperkirakan bertujuan untuk menjaga homeostatis jaringan tempatnya berada. Berdasarkan bukti ilmiah yang ada, kemampuan berdiferensiasi stem cell dewasa ini tergolong multipoten Maka stem cell dewasa ini memiliki kemampuan berdiferensiasi yang lebih rendah, jika dibandingkan dengan stem cell embrionik, hanya mampu berdiferensiasi menjadi beberapa jenis sel, umumnya yang segolongan.

Sedangkan yang menjadi kekurangan dari stem cell dewasa ini adalah konsentrasinya yang tergolong relatif jauh lebih rendah apabila dibandingkan dengan sel-sel yang telah berdiferensiasi pada jaringan dewasa.

Ditemukan bahwa, ternyata hampir seluruh jaringan dan organ pada tubuh yang telah matur, terbukti mengandung stem cell dewasa. Sehingga, penggolongan stem cell dewasa ini dilakukan berdasarkan organ dan atau golongan sel yang akan menjadi alur diferensiasinya, seperti stem cell hematopoietik, stem cell jantung, stem cell jaringan saraf (neural stem cell), stem cell mesenkimal, stem cell kulit, dan lain sebagainya. ${ }^{47}$

Telah disebutkan sebelumnya bahwa potensi diferensiasi stem cell dewasa tergolong memiliki hanya multipoten, namun jurnal-jurnal ilmiah beberapa tahun belakangan ini mendapatkan bukti bahwa terjadi adanya transdiferensiasi, yaitu adanya diferensiasi stem cell dewasa menjadi stem sel dewasa di luar alur diferensiasi yang biasanya terjadi.

\subsection{Terapi Stem Cell Menurut Syariat Agama Islam}

Sebelumnya telah disampaikan, bahwa di dalam dunia sains dewasa ini, terapi stem cell merupakan topik yang sedang hangat dibicarakan saat ini maupun ke depannya. Utamanya di kalangan dunia ilmu kedokteran, di mana dengan terapi stem cell ini, maka diharapkan tidak ada lagi penyakit degeneratif yang tidak bisa lagi disembuhkan, bahkan untuk perawatan proses penuaan (aging) sekalipun, terapi stem cell ini sangat menjanjikan, termasuk juga dalam dunia reproduksi. Namun khusus untuk reproduksi, sampai dengan saat ini belum diperbolehkan oleh menteri kesehatan sesuai dengan Peraturan Menteri Kesehatan Republik Indonesia, Nomor 32 Tahun 2018, tentang Penyelenggaraan Pelayanan Sel Punca dan/atau Sel. ${ }^{48}$ Persoalannya adalah masih adanya beberapa hal yang perlu didalami atau dikaji ulang, khususnya di kalangan umat Islam, yaitu tidak saja sekedar persoalan etika, namun kajiannya juga menyangkut persoalan kaidah, yaitu apakah dibolehkan atau tidak dibolehkan menurut syariat agama Islam? Untuk menjawab ini, maka penulis akan mengkajinya dengan menggunakan satu konsep 'metode

\footnotetext{
${ }^{46}$ Danny Halim, et.al., Stem Cell, Dasar Teori \& Aplikasi Klinis, Jakarta 13740: Erlangga, 2010, hal. 9-10.

${ }^{47}$ Fedik A. Rantam Ferdiansyah, dan Purwati, Stem Cell, Mesenchymal, Hematopoetik, Dan Model Aplikasi, Ed. 2, Cetakan 1, Surabaya 60115: Airlangga University Press, 2014, hal. 28.

${ }^{48}$ Peraturan Menteri Kesehatan Republik Indonesia, Nomor 32 Tahun 2018, tentang Penyelenggaraan Pelayanan Sel Punca dan/atau Sel, tanggal 26 Juli 2018.
} 
tafsir produk sains terapan' yang dibangun pada penelitian ini, yaitu dengan mengacu kepada hadis Rasulullah SAW, tatkala Mu'adz bin Jabal di utus ke Yaman (HR. Ahmad, Abu Daud, Tirmidzi, dan Al-Baihaqi), yang intinya tentang penggunaan tiga dalil hukum Islam, yaitu: 1.Kitabullah,2. Hadis, dan ,3. Ijtihad.

Kemudian dengan menggunakan metode tafsir produk sains terapan, yang sudah dibangun, maka produk sains terapan yang dikaji tersebut dibagi atas tiga tahapan bagian kajian sebagai berikut: .a) Bagian kajian bahan, b) Bagian kajian proses, c) Bagian kajian aplikasi. Di mana masing-masingnya, dikaji dengan menggunakan metode tafsir produk sains terapan, dengan tetap berpedoman kepada kaidah-kaidah tafsir yang berlaku. Demikian seterusnya, sampai kepada diperolehnya satu keluaran yang menjelaskan bahwa produk sains terapan tersebut dibolehkan atau tidak dibolehkan menurut syariat agama Islam. Produk sains terapan yang akan dikaji di sini, adalah produk sains terapan modern-kontemporer, yaitu 'terapi stem cell' untuk:

\section{Pengobatan Penyakit Degeneratif}

Sebelum kita membahas masalah kajian dibolehkan atau tidak dibolehkannya menurut syariat agama Islam tentang terapi stem cell untuk pengobatan penyakit-penyakit degeratif, maka penulis akan lebih dahulu menjelaskan kajian fikih tentang suatu barang atau benda yang termasuk kategori najis, dan juga pengertian tentang keterpaksaan.

Pembahasan kajian fikih diperlukan sebagai sumber dasar pengambilan keputusan atas dibolehkan atau tidak dibolehkannya penggunaan terapi stem cell menurut syariat agama Islam, kajian fikih dimaksud adalah sebagai berikut: Bahwa, barang atau benda yang termasuk dalam kategori najis menurut fikih Imam Ja'far Shadiq $^{49}$ antara lain sebagai berikut: 1) Air seni, 2) Tinja manusia atau binatang, 3) Air mani, 4) 'Darah', 5) Bangkai, 6). Anjing, 7) Babi, 8) Arak, 9) Fuqqa'(minuman yang terbuat dari sejenis gandum), 10) Keringat orang yang junub dari perbuatan haram, 11) Ahlul-kitab

Sedangkan barang atau benda yang termasuk kategori najis menurut Muhammad Ibrahim Jannati ${ }^{50}$ dalam karya bukunya dengan judul, 'Fiqih Perbandingan Lima Mazhab' (Syafi'i-Hambali-Maliki-Hanafi-Ja'fari), jilid 1, adalah sebagai berikut: 1) Anjing, 2) Babi, 3)Bangkai, 4) 'Darah'5) Mani, 6) Orang kafir ahlulkitab, 7) Nanah, 8) Muntah, 9) Kotoran manusia dan kencing, 10) Benda cair yang memabukkan, 11) Madzi, wadzi, dan wadi, 12) Keringat orang junub

13) Arak, 14) Kotoran binatang, 15) Kotoran binatang al-jallâlah, 16) Sisa makanan atau minuman. Penjelasan atas barang atau benda najis dimaksud di atas dapat dilihat dalam sumber-sumber dalil hukum Islam, yang antara lain dalam Al-Qur'an, hadis dan juga ijtihad, contohnya antara lain pada QS. al-Baqarah [2]:173 dan QS. al-An'am [6]: 145.

\footnotetext{
${ }^{49}$ Muhammad Jawad Mughniyah, Fiqh al-Imam Ja'far ash-shadiq 'Ardh wa Istidlal, Buku 1, diterjemahkan oleh Abu Zainab AB, et. al., dengan judul, Fiqih Imam Ja'far Shadiq, Cetakan 1, Jakarta: Lentera, 2009, hal. 47-56.

${ }^{50}$ Muhammad Ibrahim Jannati, Durus fi al-Fiqh al-Muqaran, diterjemahkan oleh, Ibnu Alwi Bafagih, Muhdhor Assegaf dan Alam Firdaus dengan judul, Fiqih Perbandingan Lima Mazhab (Syafi'i-Hambali-Maliki-Hanafi-Ja'fari), Jilid 1, Cet. I, Jakarta Selatan 12510: Cahaya, Rajab 1426 H/Juli 2007 M, hal. 82-94.
} 
Dari kedua contoh tentang kategori najis di atas, maka dapat dikatakan bahwa, seluruh mazhab sepakat darah adalah benda najis. Bahan darah merupakan derivatif dari stem cell, dengan demikian, maka melalui pendekatan ijtihad (qiyas) dapat dikatakan bahwa bahan stem cell juga benda najis. Selanjutnya, karena stem cell termasuk dalam benda najis, maka perlu ditinjau kembali kaidah fikihnya tentang keterpaksaan. Namun sebelumnya penulis akan jelaskan lebih dahulu tentang hal-hal yang terkait dengan tujuan pokok dari ajaran Islam (maqâshid assyari'ah), yaitu terwujudnya lima hak azazi (adh-dharûriyyât al-khams) berikut: ${ }^{.1}$ 1) Hak beragama (hifzhuddin), 2) Hak hidup (hifzhun nafs), 3) Hak berpendapat (hifzhul 'aql), 4) Hak reproduksi atau kehormatan (hifzhun nasl atau 'irdh), 5) Hak memiliki (hifzhun mâl)

Jika eksistensi salah satu dari lima hak azazi tersebut di atas terancam, maka untuk mempertahankannya boleh ditempuh 'hampir' dengan segala cara, sekalipun harus melanggar hal-hal yang dilarang, karena hal ini dianggap dalam keadaan darurat. Langkah ini didasarkan pada banyak dalil sumber hukum Islam dan kaidah ushul fiqih, antara lain adalah firman Allah, yang sudah disampaikan sebelumnya, yaitu dalam QS. al-Baqarah [2]: 173 dan juga kaidah $u$ shul fiqih yang amat populer, yaitu: adh-dharûrâtu tubîhul mahzhûrât, artinya: 'keadaan darurat menyebabkan bolehnya dilakukan hal-hal yang dilarang.'

Berdasarkan uraian dan juga penjelasan di atas, maka dapat disimpulkan bahwa, pengobatan dengan menggunakan barang najis: bangkai, daging babi, darah, termasuk juga stem cell, misalkan stem cell hematopoietik dibolehkan menurut syariat agama Islam, karena hal ini dapat dikaitkan dengan menjaga eksistensi jiwa, yaitu hak hidup atau hifzhun nafs, artinya orang yang sakit itu bisa terancam jiwanya. Maka fuqaha sepakat bahwa berobat itu hukumnya adalah wajib. Mengenai caranya, dibolehkan dengan cara apa saja, namun tidak boleh melanggar ketentuan pokok ajaran Islam, yaitu tidak menempuh jalan syirik. Ketentuan seperti ini seharusnya umat Islam mengerti, sebagaimana Rasullah SAW bersabda sebagai berikut:

'Sesungguhnya Allah SWT menurunkan penyakit dan obatnya. Dan menjadikan obat pada setiap penyakit. Maka berobatlah kamu tetapi jangan berobat dengan yang haram.' (HR. Abu Dawud, at-Tirmidzi, an-Nasa'i dan al-Baihaqi dari Abu Darda').

Maksud hadis di atas adalah bahwa, tahapan pengobatan berikut ini harus dipedomani, yaitu utamakan berobat dengan yang halal. Akan tetapi, jika ternyata ada penyakit yang belum ditemukan obatnya, dan baru diketahui obat dari benda yang haram, maka pengobatan cara yang haram itu masuk ke dalam pengecualian, sehingga boleh digunakan dengan dasar darurat, misalkan menggunakan benda najis seperti yang disebutkan di atas. Hal tersebut didasarkan pada hadis Nabi Muhammad SAW, bahwa pada zaman Nabi Muhammad SAW ada seseorang yang sedang sakit, beliau diperbolehkan meminum air kencing Unta sebagai obat (HR. Ahmad dan Abu Dawud).

Yang dimaksud dengan keadaan darurat di atas, adalah keadaan yang sangat amat terpaksa, yang apabila dibiarkan, maka akan terjadi kehancuran atau bahkan kematian. ${ }^{52}$ Sedang penetapan, apakah kondisi itu sudah termasuk ke dalam keadaan

\footnotetext{
${ }^{51}$ H. Ahmad Zahro, Fiqih Kontemporer, Menjawab 111 Masalah Aktual Hukum Islam di Zaman Kita, Cetakan I, t.tp., Qaf Media Kreativa, 2016, hal. 94.

${ }^{52}$ H. Ahmad Zahro, Fiqih Kontemporer, Menjawab 111 Masalah Aktual Hukum Islam di Zaman Kita, Cetakan I, t.tp., Qaf Media Kreativa, 2016, hal. 96.
} 
darurat atau belum, maka harus dilakukan oleh seseorang yang berakal sehat, berhati taat, dan berilmu manfaat. Namun, jika cara penyembuhan yang dimaksud mengandung kategori perbuatan syirik, maka dengan apapun alasannya tetap tidak diperbolehkan. Dan, lebih baik tetap sakit atau bahkan mati sekalipun, daripada harus menukar keyakinan atau mengotori akidah dengan perbuatan syirik, karena Allah SWT tidak berkenan mengampuni dosa syirik, sebagaimana firman Allah SWT dalam QS. an-Nisâ' [4]: 16.

Jadi pada dasarnya bahwa barang yang haram dapat digunakan sebagai obat, atau dapat dikatakan bahwa keterpaksaan membolehkan yang dilarang, namun dengan catatan dalam keadaan terpaksa dan pengobatannya tidak ada unsur perbuatan syirik. Sedang menurut Imam Ja'far Shadiq, ${ }^{53}$ selain perbuatan syirik, khamar juga termasuk benda najis yang tidak terkalahkan oleh keterpaksaan, artinya dalam keadaan terpaksa sekalipun khamar tetap kharam hukumnya, sekalipun terdapat di dalam obat dan untuk pengobatan. Demikian juga, hukum akal dan fitrah mengatakan bahwa tidak mungkin Allah SWT memberikan beban, di luar kemampuan seseorang.

Keterpaksaan diukur sesuai dengan ukuran dan kemampuannya, ketika keterpaksaan telah muncul, maka orang yang berada dalam kondisi terpaksa ini, boleh memakan sesuatu yang terlarang sekadar untuk menolak bahaya yang memaksanya itu. Maka, dari sini dikenal di kalangan fuqaha 'keterpaksaan diukur dengan ukurannya.' Hal ini ditunjukkan oleh firman Allah SWT:

"Tetapi, barang siapa dalam keadaan terpaksa (memakannya), sedang dia tidak menginginkannya dan tidak (pula) melampaui batas, maka tidak ada dosa baginya. (QS. al-Baqarah [2]: 173).

Ada satu istilah lagi 'pelampau batas,' yaitu pelaku haram tanpa keterpaksaan, sedang orang yang berlebihan, ialah orang yang terpaksa tetapi dia melakukan hal yang haram itu melebihi batas keperluannya.

Menurut Imam ash-Shadiq AS:

'Allah membolehkan bagi orang yang terpaksa atas hal-hal yang haram ketika tubuhnya sudah tidak bisa berdiri kecuali dengannya. Maka Allah memerintahnya untuk memakan (yang haram) sekadar tujuan tersebut (yaitu memperoleh kekuatan tubuh secukupnya). ' Akan tetapi sebaliknya, jika seorang yang terpaksa tidak ingin melakukan yang haram karena ingin menjaga kebersihan dirinya, dan lebih memilih bahaya, apakah dia dianggap bermaksiat dan berhak mendapat siksa dalam keadaan seperti ini? Dalam hal ini tentu dia berdosa karena menentang firman Allah SWT, sebagai berikut: Dan janganlah kamu menjatuhkan dirimu ke dalam kebinasaan (QS. al-Baqarah [2]: 195). Telah diriwayatkan dari Imam $\mathrm{AS},{ }^{54}$ bahwa beliau berkata, 'Barangsiapa terpaksa untuk memakan bangkai, darah, atau daging babi, lalu dia tidak mau memakan sesuatu darinya sehingga dia mati, maka dia telah kafir.'Selanjutnya bagaimana istinbâth hukum terapi stem cell (terapi adult stem cell), untuk pengobatan penyakit degeratif menurut syariat agama Islam? Dari

\footnotetext{
${ }^{53}$ Muhammad Jawad Mughniyah, Fiqh al-Imam Ja'far ash-shadiq 'Ardh wa Istidlal, Buku 2, diterjemahkan oleh Abu Zainab AB, et. al., dengan judul, Fiqih Imam Ja'far Shadiq, Cetakan 1, Jakarta: Lentera, 2009, hal. 837.

${ }^{54}$ Muhammad Jawad Mughniyah, Fiqh al-Imam Ja'far ash-shadiq 'Ardh wa Istidlal, Buku 2, diterjemahkan oleh Abu Zainab AB, et.al., dengan judul, Fiqih Imam Ja'far shadiq, Cetakan 1, Jakarta: Lentera, 2009, hal. 836.
} 
sepuluh langkah metode tafsir produk sains terapan pada masing-masing kajian, seperti kajian bahan, kajian proses, dan kajian aplikasi, maka keluaran kajiannya dibolehkan menurut syariat agama Islam, atas dasar keterpaksaan.

\section{Perawatan Tubuh (Aging)}

Perawatan tubuh atau aging dengan menggunakan terapi stem cell menurut syariat agama Islam dibolehkan, dengan syarat dalam satu 'kondisi keterpaksaan bersyarat,' yaitu: 1) Niat untuk berobat, 2) Dalam satu periode tertentu, 3) Dengan kapasitas atau takaran tertentu, 4) Tidak menggunakan jenis embryonic stem cell , 5) Penggunaannya dalam keadaan sadar (bukan ketagihan).

\section{Reproduksi}

Penggunaan terapi stem cell untuk reproduksi menggunakan in vitro fertilitation $(I V F)$, menurut syariat agama Islam diperbolehkan dengan syarat: 1) Dalam kondisi keterpaksaan (darurat), 2) Pembuahan antara sperma dan ovumnya berasal dari pasangan suami-isteri yang sah (inseminasi homolog), yang disebut juga dengan Artificial Insemination Husband (AIH).

\section{Kesimpulan}

berikut:

Dari penelitian ini, maka dapat diperoleh beberapa kesimpulan sebagai

1. Untuk membangun 'metode tafsir produk sains terapan' dimaksud, mengacu kepada, antara lain hadis Rasulullah SAW, tatkala Mu'adz bin Jabal di utus ke Yaman (HR. Ahmad, Abu Daud, Tirmidzi, dan Al-Baihaqi), yang intinya penggunaan tiga sumber dalil hukum Islam, yaitu: a) Kitabullah, b) Hadis, dan c) Ijtihad. Maka dibangun metode tafsir produk sains terapan, dalam bentuk blok diagram alir.

2. Metode tafsir produk sains terapan yang dibangun pada penelitian ini, relatif sederhana, mudah dimengerti, cepat, dan sistematis, dengan tingkat kebenaran yang dapat dipertanggungjawabkan.

3. Dalam penelitian ini diberikan beberapa contoh penggunaan metode tafsir produk sains terapan, antara lain produk sains terapan modern-kontemporer (terapi adult stem cell), yaitu terapi medis untuk:

a. Pengobatan Pengobatan Penyakit Degeneratif

Dari hasil kajian metode tafsir produk sains terapan diperoleh, bahwa penggunaan terapi adult stem cell dibolehkan menurut syariat agama Islam, dengan berlandaskan kepada kondisi keterpaksaan.

b. Perawatan Tubuh (aging)

Bahwa, penggunaan terapi adult stem cell untuk perawatan tubuh atau aging, menurut syariat agama Islam hukumnya dibolehkan secara bersyarat, sebagai berikut: 1) Niat untuk berobat, 2) Dalam satu periode tertentu, 3) Dengan kapasitas atau takaran tertentu, 4) Tidak menggunakan jenis terapi embrionic stem cell, 5) Penggunanya dalam keadaan sadar (bukan ketagihan).

c. Reproduksi

Bahwa, penggunaan embrio stem cell untuk proses reproduksi, menurut syariat agama Islam, hukumnya dibolehkan secara bersyarat dengan berlandaskan pada kondisi keterpaksaan. 


\section{Daftar Pustaka}

Abbas, Rafid. Ijtihad Persatuan Islam, Cetakan I, Yogyakarta: Pustaka Pelajar, 2013.

Al-'Arfaj, Abdul Ilah bin Husain. Mafhum Al-Bid'ah wa Atsaruhu fil Fatwa, diterjemahkan oleh, Mohamad Taufik Q. Hulaimi, et.al., dengan judul, Konsep Bid'ah dan Toleransi Fiqih, Cetakan Kedua, Jakarta: Al-I'tishom, Agustus 2013.

Amin, Ma'ruf. et. al., Himpunan Fatwa Majelis Ulama Indonesia Sejak 1975, Jakarta: Erlangga, 2011.

Asmawi. Perbandingan Ushul Fiqh, Ed. 1, Cetakan 2, Jakarta: Amzah, 2013.

Baidan, Nashruddin. Metodologi Penafsiran Al-Qur'an, Cetakan I, Yogyakarta: Pustaka Pelajar, 1998.

Febriani, Nur Arfiyah. Ekologi Berwawasan Gender, Dalam Perspektif Al-Qur'an, Cetakan I, Bandung: PT Mizan Pustaka, November 2014.

Halim, Danny. et.al., Stem Cell, Dasar Teori \& Aplikasi Klinis, Jakarta 13740: Erlangga, 2010.

Hamid, Syamsul Rijal. Buku Pintar Hadits, Edisi Revisi, Jakarta: Qibla, 2013.

Harjono, Hery. et. al., Mengenal Ayat-Ayat Sains Dalam Al-Qur'an: Penciptaan Manusia, Dalam Perspektif Al-Qur'an dan Sains, Jilid 1, Cetakan I, Jakarta: Widya Cahaya, 2015 M.

Humaidi. Paradigma Sains Integratif Alfarabi, Pendasaran Filosofis bagi Relasi Sains, Filsafat dan Agama, Cetakan Pertama, Jakarta Selatan 12430: Sadra Press, Jumadilakhir 1436 H/April 2015.

Jannati, Muhammad Ibrahim. Durus fial-Fiqh al-Muqaran, diterjemahkan oleh, Ibnu Alwi Bafagih, Muhdhor Assegaf dan Alam Firdaus dengan judul, Fiqih Perbandingan Lima Mazhab (Syafi'iHambali-Maliki-Hanafi-Ja'fari), Jilid 1, Cet. I, Jakarta Selatan: Cahaya, Rajab 1426 H/Juli 2007 M.

Kartanegara, Mulyadhi. et. al., Pengantar Studi Islam, Jakarta: Ushul Press, 2011.

Khallaf, Syaikh Abdul Wahhab. Al-Ijtihad fi Asy-Syariah Al-Islamiyyah, diterjemahkan oleh, Rohidin Wahid dengan judul, Ijtihad dalam Syariat Islam, Cetakan Pertama, Jakarta: Pustaka Al-Kautsar, Maret 2015.

Mahjuddin. Masail Al-Fiqh, Kasus-Kasus Aktual dalam Hukum Islam, Cetakan Ketiga, Jakarta: Kalam Mulia, 2012.

Mustaqim, Abdul. Epistemologi Tafsir Kontemporer, Cetakan III, Yogyakarta: LKIS Group, 2012.

Moeloek, Faried Anfasa. Wawancara, tanggal 31 Oktober 2017, Jakarta: 31 Oktober 2017.

Mughniyah, Muhammad Jawad. Fiqh al-Imam Ja'far ash-shadiq 'Ardh wa Istidlal, Buku 2, diterjemahkan oleh Abu Zainab AB, et. al., dengan judul, Fiqih Imam Ja'far Shadiq, Cetakan 1, Jakarta: Lentera, 2009.

National Academy of Sciences. Understanding Stem Cells, An Overview of The Science and Issues From The National Academies, National 
Academy of Engineering, t.tp: Institute of Medicine, National Research t.th.

Peraturan Menteri Kesehatan Republik Indonesia, Nomor 32 Tahun 2018, tentang Penyelenggaraan Pelayanan Sel Punca dan/atau Sel, tanggal 26 Juli 2018.

Piddock, Charles. Teknologi Masa Depan, Dari Robot Manusia hingga Rumah Pintar, Konsultan: James Lee, t.tp: National Geographic, t.th.

Rantam, Fedik A. Stem Cell Processing And Animal Trial, The $1^{\text {st }}$ Surabaya International in Stem Cell Biomedical Sciences, Unair Surabaya, November $\left(2-4^{\text {th }}\right), 2018$.

------, Fedik A, Ferdiansyah, dan Purwati. Stem Cell, Mesenchymal, Hematopoetik, Dan Model Aplikasi, Ed. 2, Cetakan 1, Surabaya 60115: Airlangga University Press, 2014.

Shihab, M. Quraish. Wawasan Al-Qur'an, Tafsir Tematik atas Pelbagai Persoalan Umat, Cetakan I, Bandung: Mizan Pustaka, Rabi’ Al-Tsani 1435 H/Februari 2014.

Sholeh, M. Asrorun Ni'am. Metodologi Penetapan Fatwa Majelis Ulama Indonesia, Penggunaan Prinsip Pencegahan dalam Fatwa, Jakarta: EmirErlangga, 2016.

Suryadilaga, M. Alfatih. et. al., Metodologi Ilmu Tafsir, Cetakan I, Yogyakarta: Teras, Mulud 1937/Februari 2005.

Zahro, H. Ahmad. Fiqih Kontemporer, Menjawab 111 Masalah Aktual Hukum Islam di Zaman Kita, Cetakan I, t.tp., Qaf Media Kreativa, 2016.

\section{Internet}

https://today.line.me/id/pc/article/Riset+ini+Ungkap+Ada+Kehidupan+di+Tubuh +Manusia+yang+Telah+Mati-B1 K6E0, Rabu,12-Juni-2019, Jam12.15 WIB.

https://tarjih.or.id/sejarah-majelis-tarjih/ Jakarta 13 Juli 2019, Jam 23.10 WIB.

https://www.google.com/search?q=bahtsul+masa\%27il\&rlz=IC9BKJA_enID7 27ID728\&oq=...Jakarta, 13 Juli 2019, Jam 23.30 WIB.

https://www.google.com/search?q=definisi+penyakit+degeratif\&rlz=IC9BKJA_e nID727ID..., tanggal 21/6/2019, jam 5.45 WIB.

https://www.google.com/search?safe=strict\&rlz=1C9BKJA_enID727ID728\&ei= P7gNXYyNIsP., tanggal 21-06-2019, jam 11.55 WIB. 